\title{
Value Addition on Nutritional and Sensory Properties of Biscuit Using Desert Truffle (Terfezia claveryi) Powder
}

\author{
Mohamed G. E. Gadallah, Ihab S. Ashoush* \\ Food Science Department, Faculty of Agriculture, Ain Shams University, Cairo, Egypt \\ Email: *ihab.ashoush@gmail.com
}

How to cite this paper: Gadallah, M.G.E. and Ashoush, I.S. (2016) Value Addition on Nutritional and Sensory Properties of Biscuit Using Desert Truffle (Terfezia claveryi) Powder. Food and Nutrition Sciences, 7, 1171-1181.

http://dx.doi.org/10.4236/fns.2016.712109

Received: September 27, 2016

Accepted: October 24, 2016

Published: October 27, 2016

Copyright $\odot 2016$ by authors and Scientific Research Publishing Inc. This work is licensed under the Creative Commons Attribution International License (CC BY 4.0).

http://creativecommons.org/licenses/by/4.0/

\begin{abstract}
Desert truffle is popular nutritious food that shows high content of protein, fibers, phenolic compounds and health promoting bioactive compounds. The aim of present study is to produce fortified functional biscuits by incorporated Dessert Truffle Powder (DTP). The effect of replacing 0 (control), 5\%, 10\% and $15 \%$ of wheat flour with DTP on chemical composition, antioxidant activity, physical properties and sensory characteristics of biscuits was investigated. The results revealed that the crude protein, ash and crude fiber content of prepared biscuits improved with the incorporation of DTP. Phenolic contents of fortified biscuits were increased gradually with increasing the level of DTP addition. Furthermore, all the selected levels of DTP incorporated in prepared biscuits showed a good ability in radical scavenging activity which ranged from $21.52 \%$ to $42.11 \%$, compared to $2.08 \%$ in case of control biscuit. Data also indicated that replacing $5 \%$ and $10 \%$ of wheat flour with DTP in biscuit preparation resulted in high significance of spread ratio 8.78 and 8.59 , respectively when compared to control biscuit which given 7.53. The lightness (L) and total intensity of biscuits were decreased from 71.19 to 60.31 and from 76.09 to 66.87 with increasing the substitution level of DTP in biscuits from $5 \%$ to $15 \%$, respectively. Biscuits incorporated with DTP at up to $10 \%$ had the acceptable mean scores by panelists for all sensory attributes. There was no significant difference in overall acceptability of biscuits incorporated with $5 \%$ and $10 \%$ of DTP which recorded 7.4 and 7.5 and control biscuit 8.2 , respectively. Thus, the present study concluded that replacing up to $10 \%$ of wheat flour with DTP enhanced the nutritional quality and antioxidant activity with acceptable sensory characteristics of biscuits. So, our study recommends encouraging the bakery products producers to incorporated DTP at $10 \%$ in biscuits production.
\end{abstract}

\section{Keywords}

Desert Truffle, Biscuit, Antioxidant Activity, Phenolic Compounds, Sensory 
Properties

\section{Introduction}

Edible mushrooms are widely consumed in many parts of the world as an important food item for their significant role in human health and nutrition. Mushrooms are still used as a food garnish or can be taken regularly as part of the human diet or as functional food. Mushrooms have been consumed for their flavor, economic and ecological values and pharmacological properties for many years [1]. Mushrooms are considered as highly nutritive food due to their low content of calories, fats, and high content of proteins and vitamins as well as their protective roll against chronic disease [2]. The medical functions of edible mushrooms include reducing cholesterol, lowering blood pressure, strengthening the immune system against diseases, combating tumors and improving the liver functions [3] [4].

Desert truffle (called EL-Fag'a or EL-Kamah) is a kind of edible fungi that grows naturally after rainy season in the deserts of Saudi Arabia, North Africa (Egypt, Tunisia, Algeria, Morocco) and other parts of the world [5]. Locally, it has an acceptable flavor and it is known as highly nutritious seasonal food. There are many species of edible desert truffle, among of them is the dark brown color truffle, Terfezia claveryi (Family, Terfeziaceae). Akyüz [6] mentioned that desert truffle was rich in linoleic, oleic and palmitic acids, and rich in flavonoids that made it show a high free radical scavenging activity. In a different study, there was a correlation between antiradical activities as antioxidant and dried desert truffles from four different Middle Eastern countries and phenolic contents [7]. Terfezia claveryi exhibits a higher oxidative inhibition on lipid peroxidation and has the ability to scavenge nitric oxide radical. Therefore, desert truffle can be used as a source of phenolic compounds that could improve antioxidant activity when added to other food products [8].

Biscuits are convenient, very popular, ready to eat, inexpensive and are considered as an important product in human diet, as well as used for infants as weaning foods. It is also used as a snack in schools for the school going children who are often underweight [9]. Not only long shelf-life of biscuits makes large scale production and distribution possible but also good eating quality makes biscuits more attractive for protein fortification and other nutritional improvements [10].

Wheat flour is the basic ingredient used in the production of biscuits which is deficient in various nutrients including vitamins, minerals and dietary fiber. Wheat flour also lacks essential amino acids such as lysine, tryptophan [11]. Partial replacements of wheat flour with other nutritional ingredients to produce functional bakery products are in high demand.

Up to our knowledge, in the literature, there is no published work on the effect of dessert truffle on the quality properties and antioxidant capacity of biscuits. Therefore, the objective of the present study was to evaluate the impact of DTP on proximate 
analysis, physical properties, color attributes, sensory evaluation and antioxidant capacity of biscuits.

\section{Materials and Methods}

\subsection{Materials}

Commercial soft wheat flour (72\% extraction), shortening, sugar and skimmed milk powder were purchased from the local market, Buraidah, Qassim, Saudi Arabia. Food grade dextrose, sodium chloride, sodium bicarbonate and ammonium bicarbonate were used in biscuits making. Sodium carbonate and methanol were obtained from ElGomhoreya Co., Cairo, Egypt. 1,1-diphenyl-2-picrylhydrazyl radical (DPPH) and Folin-Ciocalteus phenol reagent was purchased from Sigma-Aldrich Inc. (St Louis, MO, USA).

\subsection{Methods}

\subsubsection{Preparation of DTP}

Desert truffle ( Terfezia claveryi) fruiting bodies were collected from Buraidah; Qassim, Saudi Arabia during February 2016, washed, sliced and dried at $65^{\circ} \mathrm{C}$ in an air-circulated oven until constant weight. Dried slices were milled to homogenous powder and sifted through diameter 60 mesh $(250 \mu \mathrm{m})$. The DTP was kept in closed bottle at $4^{\circ} \mathrm{C}$ until analysis and biscuits making.

\subsubsection{Preparation of Biscuit Samples}

Biscuit samples were prepared by replacing $5 \%, 10 \%$ and $15 \%$ of wheat flour with DTP according to the method described by Leelavathi and Haridas [12]. The formula used was as follows: $200 \mathrm{~g}$ wheat flour, $60 \mathrm{~g}$ sugar, $50 \mathrm{~g}$ shortening, $2 \mathrm{~g}$ sodium chloride, $0.8 \mathrm{~g}$ sodium bicarbonate, $3 \mathrm{~g}$ ammonium bicarbonate, $4 \mathrm{~g}$ dextrose, $4 \mathrm{~g}$ skimmed milk powder and $40-42 \mathrm{ml}$ water. The shortening and sugar were creamed in a Hobart mixer ( $\mathrm{N}-50)$ with a flat beater for $3 \mathrm{~min}$ at $61 \mathrm{rpm}$ (speed 1). Sodium bicarbonate, sodium chloride and ammonium bicarbonate were dissolved in water and added. Skimmed milk powder was made into suspension with water and transferred to the cream. The contents were mixed for $6 \mathrm{~min}$ at $125 \mathrm{rpm}$ (speed 2) to obtain a homogenized and creamy texture. Sieved flour was added to the cream and mixed for $2 \mathrm{~min}$ at $61 \mathrm{rpm}$ (speed 1). The dough pieces were sheeted to a thickness of $3.5 \mathrm{~mm}$, cut using a circular mould ( $51 \mathrm{~mm}$ diameter) and baked at $205^{\circ} \mathrm{C}$ for $8-9 \mathrm{~min}$. After baking, biscuits were left to cool at room temperature and were wrapped tightly with polypropylene pouches and kept until further analysis.

\subsubsection{Proximate Analyses}

Wheat flour, DTP and prepared biscuit samples were analyzed for their moisture, ash, crude protein, lipids and crude fiber contents according to the methods described in AOAC [13]. The moisture content was determined by oven drying methods. Nitrogen content was estimated by micro-Kjeldahl method and converted to protein by multiplying with the factor 5.70 for wheat flour and 6.25 for DTP and prepared biscuit sam- 
ples. The lipids were determined by extracting a known weight of samples with petroleum ether, using a Soxhlet apparatus. Total carbohydrates were calculated by the difference.

\subsubsection{Preparation of Truffle Powder and Biscuits Extractions}

The extracts of DTP and biscuit samples were obtained as described by Bloor [14]. Half gram from each of DTP and biscuit samples were extracted with $20 \mathrm{ml}$ of methanol: water $(60: 40 \mathrm{v} / \mathrm{v})$. The mixture was centrifuged and the supernatant was adjusted to 25 $\mathrm{ml}$. An aliquot of their extracts were used for the quantification of total phenolic and antioxidant activity.

\subsubsection{Determination of Total Phenolic Content}

Total phenolic content was measured by the Folin-Ciocalteu assay along with spectrometer as described by Singleton et al. [15]. Aliquots of $0.5 \mathrm{ml}$ of each extracts were added to $0.5 \mathrm{ml}$ of Folin-Ciocalteu reagent, followed by addition of $0.5 \mathrm{ml}$ of an aqueous $20 \%$ solution of sodium carbonate. The mixture was stirred and allowed to stand for $30 \mathrm{~min}$. The absorbance at $765 \mathrm{~nm}$ was measured using a model UV/VIS 1201 spectrophotometer (Shimadzu, Kyoto, Japan). A blank sample consisting of water and reagents was used as a reference. Gallic acid was applied as a standard, and the results were expressed as mg Gallic Acid Equivalent (GAE)/per g.

\subsubsection{Measurement of Antioxidant Activity (DPPH Free Radical Scavenge)}

The ability of the extracts to scavenge DPPH free radicals was determined by the method described by Blois [16]. Aliquots $(100 \mu \mathrm{l})$ of each extracts were mixed with $2.9 \mathrm{ml}$ of $0.1 \mathrm{mM} \mathrm{DPPH}$ in methanol. The control samples contained all the reagents except the extract had been used. The absorbance at $517 \mathrm{~nm}$ was measured after $30 \mathrm{~min}$ of incubation at room temperature. The remaining DPPH free radical was determined by absorbance measurement against methanol blanks. The percentage scavenging effect was calculated from the reduction of absorbance against control (DPPH radical solution in methanol without sample) using the following equation:

$$
\text { Scavenging activity } \%=\left[\left(\mathrm{Abs}_{\text {control }}-\mathrm{Abs}_{\text {sample }}\right) / \mathrm{Abs}_{\text {control }}\right] \times 100
$$

\subsubsection{Physical Measurements of Biscuits}

Diameter (W) of biscuits was measured by laying six biscuits edge-to-edge with the help of a scale. The same set of biscuits was rotated $90^{\circ}$ and the diameter was remeasured. Average values of biscuits were reported in millimeter according to Srivastava et al. [17]. Thickness ( $\mathrm{T}$ ) of biscuits was measured by stacking six biscuits on top of one another and taking the average in millimeter. The spread ratio was calculated by dividing diameter $(\mathrm{W})$ by thickness $(\mathrm{T})$.

\subsubsection{Color Measurements of Biscuits}

Color of biscuit surface samples was determined according to the tristimulus color system described by Francis [18] using spectrophotometer (MOM, 100D, Hungary). Color coordinates $\mathrm{X}, \mathrm{Y} \& \mathrm{Z}$ were converted to corresponding Hunter $\mathrm{L}^{*}, \mathrm{a}^{*} \& \mathrm{~b}^{*}$ color coor- 
dinates according to formula given by manufacturer. The chroma (C) represents color saturation or purity was calculated from $\mathrm{C}=(\mathrm{a} 2+\mathrm{b} 2) 1 / 2$ and total color intensity $(\mathrm{a} 2+$ b2 + L2) $1 / 2$.

\subsubsection{Sensory Evaluation of Biscuits}

Biscuits incorporated with DTP were coded with different numbers and submitted to sensory evaluation by ten member semi trained panels of food science and human nutrition department staff. The panelists were asked to rate each sensory attribute using the control biscuit as the basic for evaluation. Biscuits were evaluated for appearance, surface color, interior color, texture, aroma, taste and overall acceptability on a 9-point hedonic scale [10].

\subsubsection{Statistical Analysis}

Descriptive values of data were represented as means \pm standard errors. Statistical analysis was performed using one way analysis of variance (ANOVA) followed by Duncan's Multiple Range Test with $\mathrm{P} \leq 0.05$ being considered statistically significant (Snedecor and Cochran, 1980) [19]. Statistical analysis was conducted with SAS program (SAS, 1996) [20].

\section{Results and Discussion}

\subsection{Chemical Composition of Wheat Flour and DTP}

Wheat flour used in biscuit preparation and DTP were analyzed for proximate composition and the data are presented in Table 1. The obtained data revealed that the DTP was significantly $(\mathrm{P} \leq 0.05)$ higher in chemical parameters contents except in carbohydrate content. Results showed that DTP was rich in minerals, protein and fiber, being $5.30 \%, 18.74 \%$ and $8.54 \%$, respectively which consider very important to use in bakery products fortification and enhance the nutritional quality of the product. The results are in accordance with [21] [22].

\subsection{Proximate Composition of Biscuit with Truffle Powder}

Table 2 Show proximate composition of biscuit samples prepared by replacing 5\%, 10\% and $15 \%$ of wheat flour with DPT compared to control sample. The results indicated that adding DTP to prepared biscuits caused significant $(\mathrm{P} \leq 0.05)$ increase in their moisture contents ranged from $5.23 \%$ to $6.29 \%$ compared to control biscuit which given $3.73 \%$. Biscuit samples with $10 \%$ and $15 \%$ desert truffle powder recorded significant $(\mathrm{P} \leq 0.05)$ increase in ash contents being $1.09 \%$ and $1.21 \%$, respectively compared to

Table 1. Proximate composition (\% on dry weight basis) of wheat flour and DTP.

\begin{tabular}{ccccccc}
\hline Samples & Moisture & Ash & Crude protein & Lipids & Crude fiber $^{\text {Carbohydrate }}$ \\
\hline Wheat flour & $11.96 \pm 0.20^{\mathrm{b}}$ & $0.78 \pm 0.03^{\mathrm{b}}$ & $10.32 \pm 0.50^{\mathrm{b}}$ & $1.43 \pm 0.02^{\mathrm{b}}$ & $0.65 \pm 0.02^{\mathrm{b}}$ & $86.82 \pm 0.55^{\mathrm{a}}$ \\
DTP & $12.82 \pm 0.05^{\mathrm{a}}$ & $5.30 \pm 0.03^{\mathrm{a}}$ & $18.74 \pm 0.35^{\mathrm{a}}$ & $2.78 \pm 0.12^{\mathrm{a}}$ & $8.54 \pm 0.13^{\mathrm{a}}$ & $64.64 \pm 0.50^{\mathrm{b}}$ \\
\hline
\end{tabular}

DTP: desert truffle powder; Data are the mean \pm SE, $n=3{ }^{*}$ : Calculated by differences. Values followed by the same letters in the same column are not significantly different $(\mathrm{p} \leq 0.05)$. 
control biscuit, this result could be attributed to the high ash content of used DTP. The same trend was found in case of crude protein and crude fiber, where the highest level $15.61 \%$ and $6.21 \%$, respectively were given by biscuit sample prepared with adding $15 \%$ of truffle powder with significant $(P \leq 0.05)$ increase compared to other biscuit samples and control one. These findings are in agreement with previous studies conducted by [23] [24] whose reported that the protein, ash, crude fiber and $\beta$-glucan content of the biscuits improved with the incorporation of grey oyster mushroom powder.

\subsection{Bioactive Compounds in Biscuits İncorporated DTP}

From the data presented in Table 3, it could be noticed that DTP are a good source of total phenolic and it had a great free radical scavenging activity. Also, there was a significant difference in total phenolic compounds that was accompanied by an elevation in the scavenging activity between all DTP treatments. These results are in agreement with those of [25]. The level of phenolic content of biscuit samples was increases proportionally with level of DTP addition. In addition, by their free radical scavenging capacities, all the level of desert truffle powder incorporated in biscuits showed a good ability in radical scavenging activity $(21.52 \%-42.11 \%)$, while it was only $2.08 \%$ in the case of the control. These results are also in agreement with those found by [26] who determined antioxidant activity and phenolic compounds in biscuit supplemented with mango by-products. Therefore, DTP can be considered as a functional food ingredient because of their antioxidant properties.

Table 2. Proximate composition (\% on dry weight basis) of biscuits incorporated with DTP.

\begin{tabular}{ccccccc}
\hline Samples & Moisture & Ash & Crude protein & Lipids & Crude fiber & Carbohydrate \\
\hline Control (0\%) & $3.73 \pm 0.04^{\mathrm{c}}$ & $0.68 \pm 0.03^{\mathrm{b}}$ & $11.75 \pm 0.07^{\mathrm{d}}$ & $6.46 \pm 0.02^{\mathrm{c}}$ & $4.44 \pm 0.13^{\mathrm{d}}$ & $76.67 \pm 0.05^{\mathrm{a}}$ \\
DTP 5\% & $5.23 \pm 0.57^{\mathrm{b}}$ & $0.78 \pm 0.06^{\mathrm{b}}$ & $12.92 \pm 0.09^{\mathrm{c}}$ & $6.71 \pm 0.14^{\mathrm{bc}}$ & $4.79 \pm 0.08^{\mathrm{c}}$ & $74.80 \pm 0.04^{\mathrm{b}}$ \\
DTP 10\% & $5.52 \pm 0.05^{\mathrm{ab}}$ & $1.09 \pm 0.02^{\mathrm{a}}$ & $14.28 \pm 0.07^{\mathrm{b}}$ & $6.93 \pm 0.06^{\mathrm{b}}$ & $5.46 \pm 0.02^{\mathrm{b}}$ & $72.24 \pm 0.08^{\mathrm{c}}$ \\
DTP 15\% & $6.29 \pm 0.04^{\mathrm{a}}$ & $1.21 \pm 0.07^{\mathrm{a}}$ & $15.61 \pm 0.05^{\mathrm{a}}$ & $7.34 \pm 0.13^{\mathrm{a}}$ & $6.21 \pm 0.03^{\mathrm{a}}$ & $69.63 \pm 0.06^{\mathrm{d}}$ \\
\hline
\end{tabular}

Data are the mean $\pm \mathrm{SE}, n=3$, Values followed by the same letters in the same column are not significantly different $(\mathrm{p} \leq 0.05){ }^{*}$ : calculated by differences.

Table 3. Total phenolic content and antioxidant activity of DTP and enriched biscuit samples.

\begin{tabular}{ccr}
\hline Samples & Total phenolic (mg GAE/g) & Scavenging activity (\%) \\
\hline DTP & $46.53 \pm 0.06^{\mathrm{a}}$ & $70.19 \pm 0.20^{\mathrm{a}}$ \\
Control (0\%) & ND & $2.08 \pm 0.02^{\mathrm{e}}$ \\
DTP 5\% & $17.97 \pm 0.04^{\mathrm{d}}$ & $3.52 \pm 0.01^{\mathrm{d}}$ \\
DTP 10\% & $26.65 \pm 0.08^{\mathrm{c}}$ & $30.08^{\mathrm{c}}$ \\
DTP 15\% & $37.68 \pm 0.03^{\mathrm{b}}$ & $42.11 \pm 0.02^{\mathrm{b}}$
\end{tabular}

DTP: desert truffle powder, Data are expressed as means \pm SE $(n=3)$. Mean values in the same column within each parameter bearing the same superscript do not differ significantly $(\mathrm{P}>0.05)$, ND: Not detected. 


\subsection{Physical Measurements of Biscuits}

The effect of replacing $5 \%, 10 \%$ and $15 \%$ of wheat flour with DTP on physical properties of biscuits was studied and the data are tabulated in Table 4. The results showed that all selected treatments resulted in significant $(\mathrm{P} \leq 0.05)$ increase in biscuit diameter when compared to control $(54.80 \mathrm{~mm})$. The higher diameter $(59.40 \mathrm{~mm})$ was given by using $10 \%$ of DTP without significant difference with biscuit sample containing $15 \%$ of DTP which recorded $59.10 \mathrm{~mm}$. Data also indicated that incorporation of $15 \%$ of DTP in biscuit preparation caused significant $(P \leq 0.05)$ increase in thickness $(8.00 \mathrm{~mm})$ compared to other treatments and control which given $7.30 \mathrm{~mm}$. It was known that biscuits having higher spread ratios are considered most desirable, in our study we found that biscuit prepared with replacing $5 \%$ and $10 \%$ of wheat flour with desert truffle powder recorded the highest spread ratio being 8.78 and 8.59 , respectively with significant $(\mathrm{P} \leq 0.05)$ increases when compared to control biscuit which given 7.53 . These results are in accordance with [21].

\subsection{Color Parameters of Biscuits}

Color of biscuit is an important characteristic for consumer preference and it depends on physicochemical parameters of used raw materials and baking. The $\mathrm{L}^{*}, \mathrm{a}^{\star}, \mathrm{b}^{*}$, total intensity and chroma for prepared biscuit samples containing DTP were analyzed and the data are shown in Table 5. It could be observed that control biscuit had the significant $(P \leq 0.05)$ increase in lightness $\left(L^{*}\right) 78.50$ and total intensity 82.90 , while the lightness was gradually decreased from 71.19 to 60.31 and total intensity was decrease from 76.09 to 66.87 with increased the adding level of DTP in biscuit from $5 \%$ to $15 \%$, respectively. Regarding to redness $\left(\mathrm{a}^{*}\right)$ and chroma, data revealed that using DTP at $15 \%$ in biscuit resulted in significant $(\mathrm{P} \leq 0.05)$ high in redness 4.31 and in chroma 28.88 compared to other treatments and control biscuit which recorded the lowest value in redness 0.73 and in chroma 26.67. These results may be occurred because of brown color of DTP and caramelization of sugar substances during biscuit baking. The results are in accordance with [22] [27] whose stated that, as the level of button mushroom powder increased, the $\mathrm{L}$ and $\mathrm{b}$ values decreased but the a value increased for crumb color of cake indicating that a darker, redder, and less yellow crumb was obtained.

Table 4. The physical properties of biscuits incorporated DTP.

\begin{tabular}{cccc}
\hline Samples & Diameter W $(\mathrm{mm})$ & Thickness T $(\mathrm{mm})$ & Spread ratio W/T \\
\hline Control (0\%) & $54.80 \pm 0.33^{\mathrm{c}}$ & $7.30 \pm 0.15^{\mathrm{b}}$ & $7.53 \pm 0.14^{\mathrm{b}}$ \\
DTP 5\% & $57.60 \pm 0.27^{\mathrm{b}}$ & $6.60 \pm 0.16^{\mathrm{c}}$ & $8.78 \pm 0.24^{\mathrm{a}}$ \\
DTP 10\% & $59.40 \pm 0.43^{\mathrm{a}}$ & $7.00 \pm 0.26^{\mathrm{bc}}$ & $8.59 \pm 0.32^{\mathrm{a}}$ \\
DTP 15\% & $59.10 \pm 0.43^{\mathrm{a}}$ & $8.00 \pm 0.26^{\mathrm{a}}$ & $7.45 \pm 0.22^{\mathrm{b}}$ \\
\hline
\end{tabular}

Data are the mean $\pm \mathrm{SE}, n=3$, Mean values in the same column bearing the same superscript do not differ significantly $(\mathrm{P} \leq 0.05)$. 


\subsection{Sensory Quality of Biscuits}

Sensory characteristics of prepared biscuits with different levels of DTP were evaluated compared to control biscuit and the results are found in Table 6 and Figure 1. It was noticed that incorporation of 5\% and 10\% DTP in biscuits caused relatively low score in appearance $(6.8 \& 6.9)$ and dark surface color $(6.8 \& 6.4)$, respectively when compared to control biscuit which recorded the highest scores in appearance 8.0 and surface color 7.9. The increase in darkness was reflected in $L^{\star}$ values (Table 4 ); which due to the dark color of used DTP. At the same time from Figure 1. It could be noticed that as the amount of DPT was increased, the appearance of biscuits became darker; data also indicated that texture and aroma of studied biscuit samples were acceptable by panelists and without significant $(\mathrm{P} \geq 0.05)$ difference with control biscuit. The taste of biscuits containing $5 \%, 10 \%$ and $15 \%$ of DTP was gradually less scores 7.4, 7.3 and 7.3, respectively compared to control biscuit which had 8.3. It may be related to the slight bitterness in taste due to high polyphenols content of DTP. It could be observed that no significant $(\mathrm{P} \geq 0.05)$ difference in overall acceptability between control biscuit 8.2 and biscuits incorporated with $5 \%$ and $10 \%$ of DTP which given 7.4 and 7.5 , respectively. These data are in agreement with [21] [22] [28].

\section{Conclusion}

This research was carried out to enhance the prepared biscuits by incorporated desert truffle powder which was considered as a good source of phytochemicals components like crude fibers, proteins, polyphenols compounds, health-promoting bioactive compounds and free radical scavenging activity. It could be concluded that replacing up to

Table 5. Effect of desert truffle powder at different levels on the color parameters of biscuits.

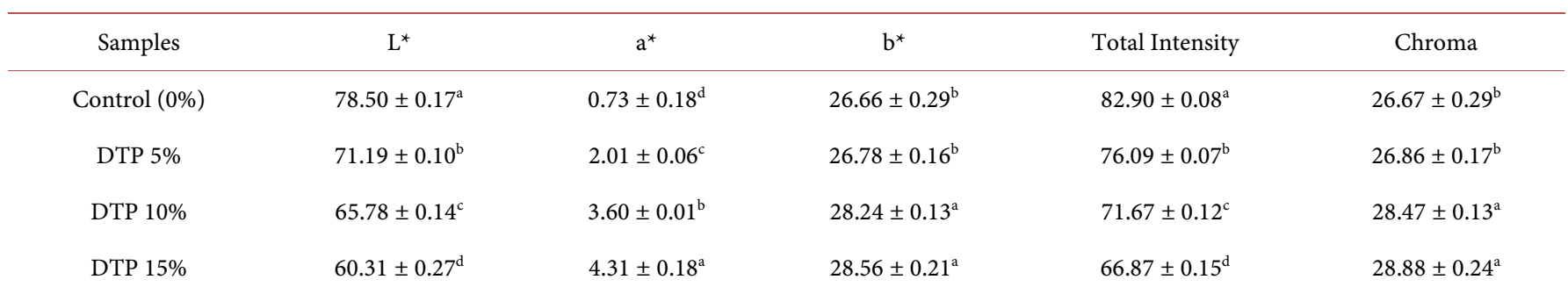

Data are the mean $\pm S E, n=6$, Mean values in the same column bearing the same superscript do not differ significantly $(P \leq 0.05)$. $L^{\star}:$ lightness; $a^{\star}:$ redness; $b^{\star}:$ yellowness.

Table 6. Sensory characteristics of biscuits incorporated with desert truffle powder.

\begin{tabular}{cccccccc}
\hline Samples & Appearance (9) & Surface color (9) & Interior color (9) & Texture (9) & Aroma (9) & Taste (9) & Overall acceptability (9) \\
\hline Control (0\%) & $8.0 \pm 0.37^{\mathrm{a}}$ & $7.9 \pm 0.43^{\mathrm{a}}$ & $8.0 \pm 0.36^{\mathrm{a}}$ & $7.8 \pm 0.36^{\mathrm{a}}$ & $7.7 \pm 0.40^{\mathrm{a}}$ & $8.3 \pm 0.30^{\mathrm{a}}$ & $8.2 \pm 0.39^{\mathrm{a}}$ \\
DTP 5\% & $7.6 \pm 0.22^{\mathrm{ab}}$ & $7.0 \pm 0.26^{\mathrm{ab}}$ & $7.0 \pm 0.26^{\mathrm{bc}}$ & $7.5 \pm 0.17^{\mathrm{a}}$ & $7.9 \pm 0.23^{\mathrm{a}}$ & $7.4 \pm 0.22^{\mathrm{b}}$ & $7.4 \pm 0.22^{\mathrm{ab}}$ \\
DTP 10\% & $6.8 \pm 0.29^{\mathrm{b}}$ & $6.8 \pm 0.25^{\mathrm{b}}$ & $7.4 \pm 0.31^{\mathrm{ab}}$ & $8.1 \pm 0.23^{\mathrm{a}}$ & $7.8 \pm 0.13^{\mathrm{a}}$ & $7.3 \pm 0.30^{\mathrm{b}}$ & $7.5 \pm 0.17^{\mathrm{ab}}$ \\
DTP 15\% & $6.9 \pm 0.46^{\mathrm{b}}$ & $6.4 \pm 0.43^{\mathrm{b}}$ & $6.4 \pm 0.34^{\mathrm{c}}$ & $6.7 \pm 0.30^{\mathrm{b}}$ & $7.3 \pm 0.26^{\mathrm{a}}$ & $7.0 \pm 0.26^{\mathrm{b}}$ & $7.2 \pm 0.29^{\mathrm{b}}$ \\
\hline
\end{tabular}

Data are the mean $\pm S E, n=10$, Mean values in the same column bearing the same superscript do not differ significantly $(P \leq 0.05)$. 


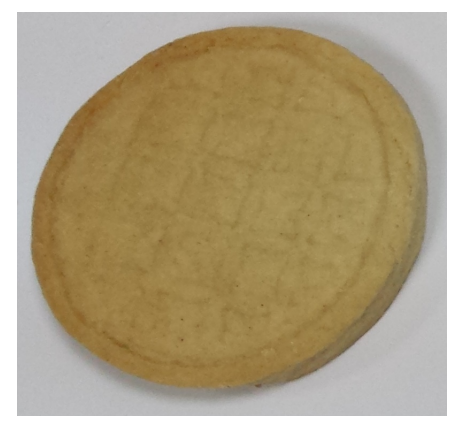

(a)

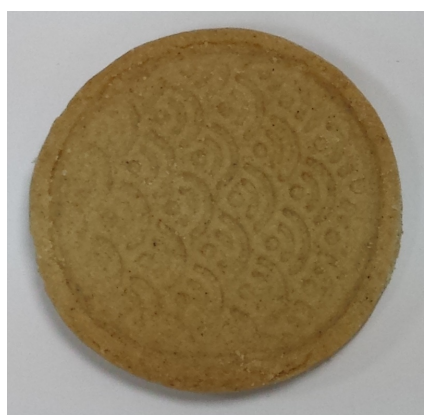

(b)

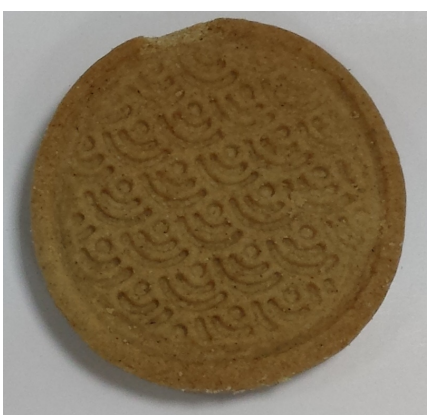

(c)

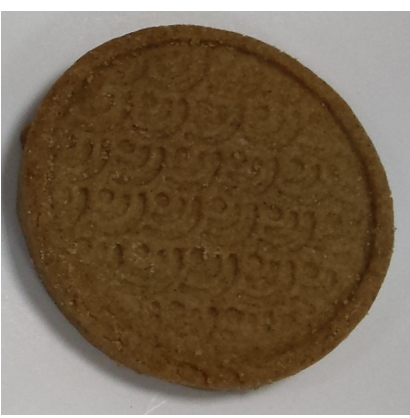

(d)

Figure 1. External appearance of biscuits with different ratios of DTP. (a) Control; (b) DTP 5\%; (c) DTP 10\%; (d) DTP 15\%.

$10 \%$ of wheat flour with desert truffle powder improved the antioxidant activity and nutritional quality with acceptable sensory characteristics of prepared biscuits. At the same time, it might be possible to maximize the benefit of the desert truffle and be a preferred functional product for consumers, especially children who like biscuits. We encourage such work to find new and novel sources of food nutraceuticals.

\section{References}

[1] Sanchez, C. (2010) Cultivation of Pleurotus ostreatus and Other Edible Mushrooms. Applied Microbiology and Biotechnology, 85, 1321-1337.

http://dx.doi.org/10.1007/s00253-009-2343-7

[2] Akyüz, M., Onganer, A.N., Erecevit, P. and Kirbag, S. (2012) Flavonoid Contents and 2,2Diphenyl-1-picrylhydrazyl Radical Scavenging Activity of Some Edible Mushrooms from Turkey: A. bisporus and Pleurotus spp. Current Topics in Nutraceutical Research, 10, 133136.

[3] Mau, J.L., Chang, C.N., Huang, S.J. and Chen, C.C. (2004) Antioxidant Properties of Methanolics Extracts from Grifola frondosa, Morchella esculenta and Termitomyces albuminosus mycelia. Food Chemistry, 87, 111-118.

http://dx.doi.org/10.1016/j.foodchem.2003.10.026

[4] Reguła, J. and Siwulski, M. (2007) Dried Shitake (Lentinulla edodes) and Oyster (Pleurotus ostreatus) Mushrooms as a Good Source of Nutrient. Acta Scientiarum Polonorum, Technologia Alimentaria, 6, 135-142.

[5] Bokhary, H.A. and Sarwat, P. (1993) Chemical Composition of Desert Truffles Terfezia clavery. Journal of Food Composition and Analysis, 6, 285-293.

http://dx.doi.org/10.1006/jfca.1993.1031

[6] Akyüz, M. (2013) Nutritive Value, Flavonoid Content and Radical Scavenging Activity of the Truffle (Terfezia boudieri Chatin). Journal of Soil Science and Plant Nutrition, 13, 143151. http://dx.doi.org/10.4067/s0718-95162013005000013

[7] Al-Laith, A.A.A. (2010) Antioxidant Components and Antioxidant/Antiradical Activities of Desert Truffle (Tirmania nivea) from Various Middle Eastern Origins. Journal of Food Composition and Analysis, 23, 15-22. http://dx.doi.org/10.1016/j.jfca.2009.07.005

[8] Murcia, M.A., Martinez-Tome, M., Jimenez, A., Vera, A., Hnorubia, M. and Parras, P. (2002) Antioxidant Activity of Edible Fungi (Truffles and Mushrooms): Losses during Industrial processing. Journal of Food Protection, 65, 1614-1622.

[9] Baljeet, S.Y., Ritika, B.Y. and Roshan, L.Y. (2010) Studies on Functional Properties and In- 
corporation of Buckwheat Flour for Biscuit Making. International Food Research Journal, 17, 1067-1076.

[10] Hooda, S. and Jood, S. (2005) Organoleptic and Nutritional Evaluation of Wheat Biscuits Supplemented with Untreated and Treated Fenugreek Flour. Food Chemistry, 90, 427-435. http://dx.doi.org/10.1016/j.foodchem.2004.05.006

[11] Ayo, J.A. and Nkama, I. (2003) Effect of Acha (D. exilis) Flour on the Physic-Chemical and Sensory Qualities of Biscuits. Nutrition \& Food Science, 33, 125-130. http://dx.doi.org/10.1108/00346650310476122

[12] Leelavathi, K. and Haridas, R.P. (1993) Development of High Fiber Biscuits Using Wheat Bran. Journal of Food Science and Technology, 30, 187-191.

[13] AOAC (2007) Official Methods of Analysis. 18th Edition, Association of Official Analytical chemists, Gaithersburg.

[14] Bloor, S. (2001) Overview of Methods for Analysis and Identification of Flavonoids. $M e$ thods in Enzymology, 335, 3-14. http://dx.doi.org/10.1016/S0076-6879(01)35227-8

[15] Singleton, V.L., Orthofer, R. and Lamuela-Raventós, R.M. (1999) Analysis of Total Phenols and Other Oxidation Substrates and Antioxidants By means of Folin-Ciocalteu Reagent. Methods in Enzymology, 299, 152-178. http://dx.doi.org/10.1016/S0076-6879(99)99017-1

[16] Blois, M.S. (1958) Antioxidant Determinations by the Use of a Stable Free Radical. Nature, 181, 1199-1200. http://dx.doi.org/10.1038/1811199a0

[17] Srivastava, Y., Semwal, A.D., Sharma, G.K. and Bawa, A.S. (2010) Effect of Virgin Coconut Meal (VCM) on the Textural, Thermal and Physico Chemical Properties of Biscuits. Food and Nutrition Sciences, 2, 38-44. http://dx.doi.org/10.4236/fns.2010.12007

[18] Francis, F.J. (1983) Colorimetry of Foods. In: Peleg, M. and Bagly, E.B., Eds., Physical Properties of Foods, The AVI Publishing Company Inc., Westport, 105-123.

[19] Snedecor, G.W. and Cochran, W.G. (1980) Statistical Methods. 7th Edition, Iowa State University Press, Ames.

[20] SAS (1996) SAS/Stat Users Guide: Statistics, System for Windows, Version 4.10 (Release 8.01 TS Level 01M0). SAS Inst., Inc., Cary.

[21] Prodhan, U.K., Linkon, K.M.R., Al-Amin, M.F. and Alam, M.J. (2015) Development and Quality Evaluation of Mushroom (Pleurotus sajor-caju) Enriched Biscuits. Emirates Journal of Food and Agriculture, 27, 542-547. http://dx.doi.org/10.9755/ejfa.2015.04.082

[22] Choudhury, M., Badwaik, L.S., Borah, P.K., Sit, N. and Deka, S.C. (2015) Influence of Bamboo Shoot Powder Fortification on Physicochemical, Textural and Organoleptic Characteristics of Biscuits. Journal of Food Science and Technology, 52, 6742-6748. http://dx.doi.org/10.1007/s13197-015-1709-3

[23] Ory, R.L. and Conkerton, E.J. (1983) Supplementation of Bakery Items with High Protein Peanut Flour. Journal of the American Oil Chemists' Society, 60, 986-989. http://dx.doi.org/10.1007/BF02660213

[24] Rosli, W.I.W., Nurhanan, A.R. and Aishah, M.S. (2012) Effect of Partial Replacement of Wheat Flour with Oyster Mushroom (Pleurotus sajor-caju) Powder on Nutritional Composition and Sensory Properties of Butter Biscuit. Sains Malaysiana, 41, 1565-1570.

[25] Chaturvedi, P., Khare, K.B., Kwape, T. and Makholwa, K. (2015) Free Radical Scavenging and Antioxidant Properties of a Truffle, Kalaharituber pfeilii Found in Kalahari Deserts of Botswana. International Journal of Bioassays, 4, 4533-4537.

[26] Ashoush, I.S. and Gadallah, M.G.E. (2011) Utilization of Mango Peels and Seed Kernels Powders as Sources of Phytochemicals in Biscuit. World Journal of Dairy \& Food Sciences, 
6, 35-42.

[27] Salehi, F., Kashaninejad, M., Asadi, F. and Najafi, A. (2016) Improvement of Quality Attributes of Sponge Cake Using Infrared Dried Button Mushroom. Journal of Food Science and Technology, 53, 1418-1423. http://dx.doi.org/10.1007/s13197-015-2165-9

[28] Desayi, D. (2012) Development, Sensory Evaluation and Microbial Analysis of Mushroom Fortified Biscuits. International Journal of Food, Agriculture and Veterinary Sciences, 2, 183-186.

Submit or recommend next manuscript to SCIRP and we will provide best service for you:

Accepting pre-submission inquiries through Email, Facebook, LinkedIn, Twitter, etc.

A wide selection of journals (inclusive of 9 subjects, more than 200 journals)

Providing 24-hour high-quality service

User-friendly online submission system

Fair and swift peer-review system

Efficient typesetting and proofreading procedure

Display of the result of downloads and visits, as well as the number of cited articles

Maximum dissemination of your research work

Submit your manuscript at: http://papersubmission.scirp.org/

Or contact fns@scirp.org 